\title{
The Effects of Supplemented Biscuit with Different Levels of Olive Pomace on Feeding Diabetic Rats
}

\author{
M. F. Elkotb, S. M. Saleh and S. Y. Elsanat \\ Department of Food Technology, Faculty of Agriculture, Kafrelsheikh University, \\ Egypt
}

\begin{abstract}
THIS WORK was conducted to study the effects of different levels of olive pomace (OP) on body weight gain, feed intake and feed conversion efficiency of rats. Experimental rats nutrition supplemented to diabetic rats ( 7 rats in each group) for 42 day. After the $42^{\text {nd }}$ day, chemical analysis of marker enzyme (MDA, TAC and SOD), liver function (ALT, AST and T-protein), kidney functions (Creatinine and Blood urea), lipid profile (triglycerides, total cholesterol, HDL, LDL and vLDL), and haematological analysis was recorded. The highest effects of supplementation of olive pomace in rats nutrition on body weight of rats, were 200 , 200,205 and $225 \mathrm{~g}$, of treatments $(2.5,5,7.5$ and $10 \%$ of OP), respectively as compared with normal control ( $0 \% \mathrm{OP})$, which was $190 \mathrm{~g}$. Also, the most effective treatments were $10 \%$ of OP of blood biochemical and haematological parameters, comparing with normal nutrition. Therefore, it is recommended to add olive pomace at $5 \%, 7.5 \%$ and $10 \%$ in rats nutrition to improve performance and health.
\end{abstract}

Keywords: Rats, Nutrition, Supplementation, Diabetic rats, Chemical analysis, Olive pomace with biscuit, Olive pomace and Biscuit

\section{Introduction}

Medicinal plants having various phytochemicals and bioactive compounds such as trace metal ions, vitamins, alkaloids, carotenoids, polyphenols, fats, carbohydrates, and proteins are involved in enhancing long-term health benefits. Although the relationship between lipids abnormalities and diabetes is complex, there is usually a specific lipid abnormality found in diabetes. Also, high triglycerides, high total cholesterol and low HDL-C levels were commonly seen in diabetes. The abnormal high level of lipids in diabetes is mainly due to the increase in the mobilization of free fatty acids from the peripheral depots, since insulin inhibits the hormone sensitive lipase but glucagons, catecholamines and other hormones enhance lipolysis. The marked hyperlipidemia that characterizes the diabetic state may therefore be regarded as a consequence of the fat depots (Melis, 1995).

Olive (Oleaeuropaea L.) fruit is a key ingredient of a Mediterranean diet, and its diseasepreventing effects have been attributed to its fatty acid profile, as well as the presence of a plethora of bioactive components, such as tocopherols, phospholipids, biophenols and triterpenic acids (Sravanthi and Rao, 2014). Olive fruit is a particularly rich source of maslinic and oleanolic acids, while ursolic and betulinic acids have been reported at lower amounts. These compounds are presented at high ratios in the epicarp of the fruit, forming part of the waxes that cover them; oleanolic acid has also been found in the endocarp (wood shell and seed). mTriterpenic acids are a group of phytochemicals that has been studied extensively for their pharmacological properties, because pentacyclicterpene acids present potent anti-oxidant, anti-inflammatory, anti-tumour and anti-microbial activity. In addition, the anti-proliferative activity of triterpenic acids against cancer lines has been also documented. The simultaneous determination of triterpenic acids using chromate-graphic and spectroscopic methods has been thoroughly studied over recent years, mainly because of their similar chemical structure. On the other hand, the recovery of triterpenic acids from olive fruit has been poorly investigated, although it is a crucial step of the overall analytical process that leads to the quantification of the target phytochemical. 
The significance of extraction in developing analytical methodologies for accurate estimation of bioactive compounds in functional foods has been highlighted by Goulas and George (2011).

Additionally, the ripening stage at harvest interferes with pectic polysaccharides found in the olive pomace cell walls, due to the presence of calcium chelating dimers, there by changing the nutritional value of this by product. Based on the above characteristics, OPs have been proposed as alternative sources of nutrients for domestic animal feeding. Among domestic ruminants, goats seem to be adapted for utilizing this highlignin-cellulose/ low protein feedstuff (Molina et al., 2003).

The aim of the present study was to explore the effects of olive pomace as a new source of antioxidant on the productive and physiological parameters of rats (the levels of liver marker enzymes, aspartate transaminase (AST), alanine transaminase (ALT) in serum) in addition to malondialdehyde (MDA) content, and the activities of antioxidants such as superoxide dismutase (SOD).

\section{Materials and Methods}

\section{Samples}

Olive pomace samples $(20 \mathrm{~kg})$ extracted from (Oleaeuropaea L.) were kindly obtained from Kenana Mill, Abd-Elsalam Hegazy, Wadi Elnatrun, Behira, Egypt. Samples were washed and dried in an electric air oven at a temperature of $50{ }^{\circ} \mathrm{C}$ for $24 \mathrm{hrs}$, then ground into a fine powder to pass through 60 mesh screen sieve. The ground powder was subjected at ambient temperature to gamma irradiation from Co-60 source at National Center for Radiation Research and Technology, (NCRRT), Nasr City, Cairo, Egypt. The irradiation facility used was Egypt Mega Gamma-1 type "J-6500". The applied dose was $60 \mathrm{kGy}$. Radiation dose was calibrated using small pieces of experimentation. The raw and processed samples were hold in tight glass jars and kept at 4 ${ }^{\circ} \mathrm{C}$ until used.

\section{Experimental animals}

Forty two male albino rats $(150-170 \mathrm{~g})$ were procured from the animal house of Faculty of Pharmacy, Mansoura University, Egypt. All rats were housed in microlon boxes in a controlled environment (temperature $25 \pm 2^{\circ} \mathrm{C}$ and $12 \mathrm{hr}$ dark/ light cycle) with standard laboratory diet and water ad libitum.

Egypt. J. Sus. Agric. Sci. 43, No. 3 (2017)

\section{Preparation of biscuit}

The method and formula of Nnam and Nwokocha (2003) were used to prepare the biscuit samples as shown in Table 1. Blends containing $2.5,5.0,7.5$ and $10 \%$ of olive pomace were used as supplemention of wheat flour (72\% extraction). The control biscuits formulas were prepared using $200 \mathrm{~g}$ of flour mixture, $66.67 \mathrm{~g}$ of margarine, $66.67 \mathrm{~g}$ of ground sugar, $32.33 \mathrm{ml}$ of water, $4 \mathrm{~g}$ of double acting baking powder and $8 \mathrm{~g}$ of whole egg as shown in Table 1.

\section{Design of biological experiments}

The experiments were conducted on forty two male albino rats (mean weight $160 \pm 10$ ). Animals were housed in well-aerated cages under hygienic condition. They will be fed on wheat biscuit according to Eskander and Jun (1995), given tap water ad libitum and left to accommodate one week before experimental use. After the period of adaptation, animals were randomly divided into six groups with seven rats in each group. Group one $\left(\mathrm{G}_{1}\right)$ was reserved as normal control, groups two-six animals were administrated interperitoneal (IP) injection with single dose of alloxan solution (120 mg/kg body weight) after 24 $\mathrm{hr}$ fasting to induce hyperglycemia and divided as follows:

G1: Negative control (-ve) fed basal on wheat biscuit with $0 \%$ olive pomace.

G2: Positive control (+ve), diabetic rats fed on wheat biscuit with $0 \%$ olive pomace.

G3: Diabetic rats fed on prepared biscuit supplementing with $2.5 \%$ olive pomace.

G4: Diabetic rats fed on prepared biscuit supplementing with $5.0 \%$ olive pomace.

G5: Diabetic rats fed on prepared biscuit supplementing with $7.5 \%$ olive pomace.

G6: Diabetic rats fed on prepared biscuit supplementing with $10 \%$ olive pomace.

After one week of acclimatization, the six experimental nutrition were randomly assigned and fed to the rats adlibitum for a total of six weeks (42 days).

\section{Body weight}

From each group 7 rats were weighted individually at the begining of the experiment and on the $42^{\text {nd }}$ day post supplementation and consumed nutrition were recorded for calculation of weight gain and feed conversion rate (Allam et al., 2016). 
TABLE 1. Formula used in making biscuits

\begin{tabular}{lccccc}
\hline Components & Control & Blend 1 (2.5\%) & Blend 2 (5\%) & Blend3 (7.5\%) & $\begin{array}{c}\text { Blend 4 } \\
(\mathbf{1 0 \%})\end{array}$ \\
\hline Flour (72\%)(g) & 200 & 195 & 190 & 185 & 180 \\
Olive pomace $(\mathrm{g})$ & 0 & 5.0 & 10.0 & 15.0 & 20.0 \\
Margarine(g) & 66.67 & 66.67 & 66.67 & 66.67 & 66.67 \\
Sugar (g) & 66.67 & 66.67 & 66.67 & 66.67 & 66.67 \\
Water(ml) & 32.33 & 32.33 & 32.33 & 32.33 & 32.33 \\
Baking powder (g) & 4 & 4 & 4 & 4 & 4 \\
Whole egg (g) & 8 & 8 & 8 & 8 & 8 \\
\hline
\end{tabular}

\section{Blood samples}

Samples were collected from the eye can thus by heparinized tubes after 42 days from the beginning of the experiment. Then, each blood sample was divided into two portions. First portion was centrifugated to obtain the blood serum. Serum samples were kept at refrigerator under freezing conditions for determination of the lipid profile (Triglycerides, total cholesterol, HDL-c, LDL-c and VLDL-c). The second portion was treated with $10 \%$ of ethylene diaminetetracetic acid (EDTA) with a good shaking to determine complete blood count (CBC) as a haematological analysis (Mahmoud et al., 2013).

\section{Chemical analysis of blood \\ Determination of serum glucose}

Blood glucose was determined in blood serum using a commercial kit (Spain React Company, Spain) according to the method recommended by Trinder (1969).

\section{Determination of malondialdehyde (MDA)}

From the individual $2 \mathrm{ml}$ of blood collected, serum was separated by centrifuging of the blood sample at $3000 \mathrm{rpm}$ for $5 \mathrm{~min}$. Then the serum MDA was measured using the method of Deepa $e t$ al. (2012). Serum $(100 \mu 1)$ is diluted to $500 \mu 1$ with distilled water; the sample was kept in boiling water bath for $15 \mathrm{~min}$. To the diluted samples $1 \mathrm{ml}$ of tricoloracetic acid, TCA-2Thiobarbituric acid (TBA)-HCL reagent was added. The reaction mixture was cooled and centrifuged. The supernatant was taken and the optical density of the pink color formed was read at wavelength $535 \mathrm{~nm}$. The MDA $(\mu \mathrm{mol} / \mathrm{ml})$ in the given sample was calculated by the obtained absorbance against the standard graph and multiplied by the respective dilution factors.

\section{Determination of total antioxidant capacity (TAC)}

The total antioxidant capacity of plasma was evaluated by applying the ferric reducing antioxidant power (FRAP) assay according to the method of Benzie et al. (1996). The FRAP reagent was prepared extempore by mixing $300 \mathrm{mmol} / \mathrm{L}$ acetate buffer, pH 3.6 with 2,4,6-tripyridylstriazine (TPTZ) solution (10 $\mathrm{mM}$ in $40 \mathrm{mMHCl})$ and $20 \mathrm{mmol} / \mathrm{I} \mathrm{FeCl}_{3}$ solution in ratio10:1:1, respectively and was pretempered at $37^{\circ} \mathrm{C}$. The reaction was performed by adding $100 \mu \mathrm{L}$ plasma, previously diluted 1:1 with distilled water, to 900 $\mu \mathrm{L}$ FRAP reagent and the mixture was incubated for $25 \mathrm{~min}$ at $37^{\circ} \mathrm{C}$. The absorbance was measured on $593 \mathrm{~nm}$ compared to a blank mixture where 100 $\mu \mathrm{L}$ water was added to the FRAP reagent instead of plasma. Aqueous solutions of known $\mathrm{Fe}^{2+}$ ratio, in range 0.2 to $1 \mathrm{mmol} / \mathrm{L}\left(\mathrm{FeSO}_{4} \cdot 7 \mathrm{H}_{2} \mathrm{O}\right.$; Sigma Aldrich, USA) were used for creating the standard curve. The results were expressed in $\mathrm{mmol} / \mathrm{L} \mathrm{Fe}^{2+}$.

\section{Determination of total superoxide dismutase} activity (SOD)

The assay of superoxide dismutase was done according to the procedure of Das et al. (2000). In this method, $1.4 \mathrm{ml}$ aliquot of the reaction mixture (containing $1.11 \mathrm{ml}$ of 50 mmolphosphate buffer of $\mathrm{pH} 7.4,0.075 \mathrm{ml}$ of $20 \mathrm{nmol}$ Methionine, 0.04 $\mathrm{ml}$ of $10 \mathrm{mmol}$ hydroxylamine hydrochloride and $0.1 \mathrm{ml}$ of $50 \mathrm{mmol}$ EDTA) was added to $100 \mathrm{Fl}$ of the sample extract and incubated at $30^{\circ} \mathrm{C}$ for $5 \mathrm{~min}$. $80 \mathrm{Fl}$ of $50 \mathrm{FM}$ riboflavin was then added and the tubes were exposed for $10 \mathrm{~min}$ to $200 \mathrm{~W}$ - Philips fluorescent lamps. After the exposure time, $1 \mathrm{ml}$ of greiss reagent (mixture of equal volume of $1 \%$ sulphanilamide in $5 \%$ phosphoric acid) was added and absorbance of the color formed was measured at wavelength $543 \mathrm{~nm}$. One unit of enzyme 
activity was measured as the amount of SOD capable of inhibiting $50 \%$ of nitrite formation under assay conditions. The activity of SOD is expressed as unit/g protein. Inhibition percentage was calculated from the optical density (OD) of each tube with varying amounts of enzyme (red cell extract) and optical density of the control without enzyme.

$$
\% \text { inhibition }=1-\frac{\text { As } \times 100}{\mathrm{Ac}} \times 100
$$

where:As $=$ the absorbance of the sample and $\mathrm{Ac}=$ the absorbance of the control.

\section{Analysis of liver functions}

Glutamic pyruvic transaminase (GPT) or alanine amino transferase enzyme (ALT) and glutamic-oxaloacetic transaminase (GOT) or aspartate amino transferase (AST) activities were determined according to the method described by Varley et al. (1980). Protein content was determined by using a commercial kit (Biomed Company, Germany) according to the method described by Henry (1964). Albumin was determined using a commercial kit (Biomed Company, Germany) according to the method recommended by Doumas et al. (1971). The globulin values were obtained by subtracting albumin from total protein.

Analysis of kidney functions (urea and creatinine)

Creatinine was determined using a commercial kit (Biomed Company, Germany) according to the method described by Jaffé (1986). Blood urea content was estimated using a commercial kit (Biomed Company, Germany) according to the method described by Patton and Crouch (1977).

\section{Analysis of serum lipids}

The ratio of total cholesterol (TC), triglycerides levels and high Density Lipoprotein (HDL) cholesterol in the serum were determined without extraction using enzymatic colorimetric methods with commercially available kits (cholesterol, kit 276-64909; high-density lipoprotein kit 27867409 and triglyceride kit 274-69807; Wakse chemicals, Osaka, Japan) according to the method recommended by Kim and Shin (1998). Low density lipoprotein (LDL) and very low density (vLDL) cholesterol in serum ratios were calculated as described by Wardlaw and Snook (1990) as the following:

LDL- cholesterol $(\mathrm{mg} / \mathrm{dl})=\mathrm{TC}-(\mathrm{vLDL}+$ HDL-c).

Egypt. J. Sus. Agric. Sci. 43, No. 3 (2017)
vLDL-cholesterol $(\mathrm{mg} / \mathrm{dl})=($ Triglyceride $/ 5)$

Atherogenic index is an indication for susceptibility for atherosclerosis. It was calculated using the following equation as described by Kawase et al. (2000):

$$
\text { Atherogenic index }(\mathrm{Al})=\frac{\text { Total cholesterol }(\mathrm{TC}) \cdot \text { HDL }- \text { cholestrol }}{\text { HDL }- \text { cholesterol }}
$$

Effect of nutrition on haematological analysis

All hematological tests were made using apparatus namely ABX Micros60 which is a fully automated hematology analyzer from Sysmex Corporation international company (Nakul et al., 2003).

\section{Statistical analysis}

Statistical analysis of all data was done using the statistical software package (Costat, 2005). All comparisons were first subjected to one-way analysis of variance (ANOVA) and significant differences between treatment means were determined using Duncan's multiple range test at $\mathrm{p}<0.05$ as the level of the significance (Duncan, 1955).

\section{Results and Discusion}

Effect of supplemented biscuit with different levels of olive pomace on body weight development of growing rats

Data in Table 2 revealed that initial body weight at the beginning of the experiment, ranged from 150 to $170 \mathrm{~g}$ of all groups. While, the most effective of supplementation of olive pomace (OP) in rats nutrition (Biscuit) on body weight gain of rats, ranged from 25.0 to $36.7 \%$, of treatments $(2.5,5,7.5$ and $10 \%$ OP), after 6 weeks. As compared with control negative $(0 \% \mathrm{OP})$, which was $26.7 \%$. Olive pomace supplementation improved final body weight gain (\%) compared with rats fed with control diet after 6 weeks of the experimental period $(\mathrm{p} \leq 0.05)$. Olive pomace supplementation did not have significant effect on body weight gain (\%) (Table 1). High levels of olive pomace diets may decrease the viscosity of the gut contents, which impedes the circulation and absorption of nutrients, causing an increment in body weight gain (Zarei1 et al., 2011).

\section{Blood serum glucose levels of rats fed on prepared biscuit}

Table 3 illustrated the blood glucose levels of normal control and diabetic groups through the 
TABLE 2. Effect of feeding on supplemented biscuit with different olive pomace ratios on body weight development of diabetic rats

\begin{tabular}{lcccc}
\hline Groups & Initial body weight (g) & Final body weight (g) & $\begin{array}{c}\text { Change body weight } \\
(\mathbf{g})\end{array}$ & Body weight gain (\%) \\
\hline Group 1 & $150^{\mathrm{c}}$ & $190^{\mathrm{e}}$ & $40^{\mathrm{c}}$ & $26.7^{\mathrm{c}}$ \\
Group 2 & $150^{\mathrm{c}}$ & $175^{\mathrm{d}}$ & $25^{\mathrm{d}}$ & $16.7^{\mathrm{d}}$ \\
Group 3 & $160^{\mathrm{b}}$ & $200^{\mathrm{c}}$ & $40^{\mathrm{c}}$ & $25.0^{\mathrm{c}}$ \\
Group 4 & $150^{\mathrm{c}}$ & $200^{\mathrm{c}}$ & $50^{\mathrm{b}}$ & $33.4^{\mathrm{b}}$ \\
Group 5 & $150^{\mathrm{c}}$ & $205^{\mathrm{b}}$ & $55^{\mathrm{a}}$ & $36.7^{\mathrm{a}}$ \\
Group 6 & $170^{\mathrm{a}}$ & $225^{\mathrm{a}}$ & $55^{\mathrm{a}}$ & $32.4^{\mathrm{b}}$ \\
\hline
\end{tabular}

Group 1: control negative, Group 2: control positive, Group 3: with $2.5 \%$ of Olive pomace, Groups 4: $5 \%$ of Olive pomace, Group 5: 7.5\% of Olive pomace, Group 6: $10 \%$ of Olive pomace, respectively.

experimental period (6 weeks). Blood glucose levels of diabetic groups were markedly higher than that of normal control rats (G1). The results also indicated that, biscuit contained olive pomace caused a significant decrease in blood glucose levels of the diabetic rats (G3 to G6) comparing with diabetic control rats $(\mathrm{G} 1)$ and diabetic rats fed on biscuit contained wheat flour only (G2).

This decrement was observed after 2 weeks of feeding till the end of experimental periods, the reduction increased with prolonging the feeding time where, it reached the normal levels at the end of experiments. These results are in agreement with Koyama et al. (2003).

Effect of feeding on supplemented biscuit with different olive pomace ratios on some serum marker enzyme parameters

Data in Table 4 revealed that the malondialdehyde (MDA) of control negative of rats was $3.7 \mu \mathrm{mol} / \mathrm{ml}$. While, the most effective treatment was biscuit with olive pomace at ratio $(10 \%)$, which decreased MDA levels to $3.4 \mu \mathrm{mol} / \mathrm{ml}$, followed by the effect of the treatment of biscuit with olive pomace at ratios (7.5, 5 and 2.5\%), which reduced MDA to 3.5, 3.5 and $3.6 \mu \mathrm{mol} / \mathrm{ml}$,respectively. The same table exhibited the total antioxidant capacity (TAC) that increased from $0.53 \mathrm{mmol} / \mathrm{L}$ of normal nutrition of rats to reach $0.55 \mathrm{mmol} / \mathrm{L}$ at treatment of biscuit with olive pomace by ratio (10\%). Also, feeding on the biscuit supplemented with olive pomace at the ratio $(2.5,5$ and $7.5 \%)$ raised TAC level to $0.53,0.54$ and $0.55 \mathrm{mmol} / \mathrm{L}$, respectively.

From Table 4, we can notice that the total superoxide dismutase enzyme (SOD) of normal nutrition of rats was $1.67 \mathrm{U} / \mathrm{mg}$ protein. The supplementation of biscuit with olive pomace at ratios $(5,7.5$ and $10 \%)$, increased SOD levels to $1.68,1.68$ and $1.69 \mathrm{U} / \mathrm{g}$, respectively. While, supplementation of biscuit with olive pomace at ratio $2.5 \%$ had no effect. This finding was in the same line with Sohair et al. (2015), who found that olive pomace supplementation affected antioxidative parameters of bucks subjected to dizocilpine oxidative stress which increased to $644.59 \mathrm{U} / \mathrm{g}$ and $2.89 \mu \mathrm{mol} / \mathrm{g}$, of SOD and TAC, after two months, respectively, as compared to the effect of olive pomace supplementation after first month on SOD and TAC, which were $567.00 \mathrm{U} / \mathrm{g}$ and $1.77 \mu \mathrm{mol} / \mathrm{g}$, respectively.The obtained data are in agreement with those of Mahmoud et al. (2013), who found that the effect of the supplementation of broiler diets with olive oil (1\%), on superoxide dismutaseenzyme (SOD) was $0.82 \mathrm{U} / \mathrm{mg}$, after 42 days compared to control, which were 0.33 and $0.43 \mathrm{U} / \mathrm{mg}$, respectively.On the other hand, the decreased value of CAT from 23.42 to $22.54 \mathrm{mmol} / \mathrm{L}$ was determined.

Effect of feeding on supplemented biscuit with different olive pomace ratios on liver functions

Alanine amino transferase (ALT) and aspartate amino transferase (AST) enzymes activities are known as cytosolic marker enzymes reflecting hepatocellular necrosis as they are released into the blood after the damage of the cell membrane. Therefore, both enzymes are used as indicators for hepatic damage (Andallu and Vardacharyulu, 2001). Data in Table 5 showed that ALT were raised from $17.36 \mathrm{U} / \mathrm{L}$ of normal nutrition of rats to reach 18.09 and $18.14 \mathrm{mmol} / \mathrm{L}$ at treatment of biscuit with olive pomace by ratios (7.5 and $10 \%)$. Also, the effect of supplemented biscuit with olive pomace by ratios $(2.5,5$ and $7.5 \%)$ which raised ALT level to 17.78 and $17.94 \mathrm{U} / \mathrm{L}$, respectively.The same Table showed that AST of normal nutrition of rats was $36.25 \mathrm{U} / \mathrm{L}$ which decreased to $36.02,35.92,35.54$ and 35.12U/Lof supplemented biscuit with olive pomace by ratio $(2.5,5,7.5$ and $10 \%)$, respectively.

Egypt. J. Sus. Agric. Sci . 43, No. 3 (2017) 
TABLE 3. Effect of feeding on supplemented biscuit with different olive pomace ratios on blood serum glucose (mg/ dl) after 6 weeks of rats fed

\begin{tabular}{lccccc}
\hline $\begin{array}{l}\text { Dietary } \\
\text { Groups }\end{array}$ & \multicolumn{3}{c}{ Fasting blood glucose } \\
& 2weeks & 3weeks & 4weeks & 5weeks & 6weeks \\
\hline $\mathrm{G}_{1(\text { control) }}$ & $106.1^{\mathrm{i}}$ & $104.3^{\mathrm{i}}$ & $107.4^{\mathrm{i}}$ & $100.8^{\mathrm{i}}$ & $102.5^{\mathrm{i}}$ \\
$\mathrm{G}_{2}{ }^{\mathrm{A}}$ & $284.6^{\mathrm{a}}$ & $267.0^{\mathrm{a}}$ & $210.1^{\mathrm{e}}$ & $226.6^{\mathrm{d}}$ & $219.5^{\mathrm{e}}$ \\
$\mathrm{G}_{3}{ }^{\mathrm{B}}$ & $252.1^{\mathrm{b}}$ & $182.0^{\mathrm{f}}$ & $176.1^{\mathrm{f}}$ & $167.3^{\mathrm{g}}$ & $158.4^{\mathrm{g}}$ \\
$\mathrm{G}_{4}{ }^{\mathrm{C}}$ & $228.2^{\mathrm{c}}$ & $139.0^{\mathrm{h}}$ & $132.6^{\mathrm{h}}$ & $107.7^{\mathrm{i}}$ & $102.3^{\mathrm{i}}$ \\
$\mathrm{G}_{5}{ }^{\mathrm{C}}$ & $225.3^{\mathrm{d}}$ & $128.0^{\mathrm{h}}$ & $122.7^{\mathrm{h}}$ & $103.1^{\mathrm{i}}$ & $101.5^{\mathrm{i}}$ \\
$\mathrm{G}_{6}{ }^{\mathrm{D}}$ & $217.1^{\mathrm{e}}$ & $120.0^{\mathrm{h}}$ & $116.1^{\mathrm{i}}$ & $102.3^{\mathrm{i}}$ & $100.4^{\mathrm{i}}$ \\
\hline
\end{tabular}

Each value is an average of three determinations.

A, B. C, D and E: comparison of means of serum glucose $(\mathrm{mg} / \mathrm{dl})$ by olive pomace supplementation.

$\mathrm{a}, \mathrm{b}, \mathrm{c}, \mathrm{d}$ and e: comparison of means of serum glucose $(\mathrm{mg} / \mathrm{dl})$ by feeding period (weeks).

Means with different superscripts (capital letters in the same column and small letters in the same row) differ significantly $(\mathrm{P}<0.01)$

TABLE 4. Effect of feeding on supplemented biscuit with different olive pomace ratios on some serum marker enzyme parameters (MDA $\mu \mathrm{mol} / \mathrm{ml}$, TAC mmol/l andSOD U/mg protein) of diabetic rat groups

\begin{tabular}{cccc}
\hline Groups & MDA $(\mu \mathbf{m o l} / \mathbf{m l})$ & TAC $(\mathbf{m m o l} / \mathbf{l})$ & SOD $($ U/mg protein $)$ \\
\hline Group 1 & $3.7^{\mathrm{a}}$ & $0.53^{\mathrm{c}}$ & $1.67^{\mathrm{c}}$ \\
Group 2 & $3.7^{\mathrm{a}}$ & $0.53^{\mathrm{c}}$ & $1.67^{\mathrm{c}}$ \\
Group 3 & $3.6^{\mathrm{b}}$ & $0.53^{\mathrm{c}}$ & $1.67^{\mathrm{c}}$ \\
Group 4 & $3.5^{\mathrm{c}}$ & $0.54^{\mathrm{b}}$ & $1.68^{\mathrm{b}}$ \\
Group 5 & $3.5^{\mathrm{c}}$ & $0.55^{\mathrm{a}}$ & $1.68^{\mathrm{b}}$ \\
Group 6 & $3.4^{\mathrm{d}}$ & $0.55^{\mathrm{a}}$ & $1.69^{\mathrm{a}}$ \\
\hline
\end{tabular}

MDA: Malondialdehyde, TAC: Total antioxidant capacity and SOD: Superoxide dismutase activity. a, b, $\mathrm{c}$ and $\mathrm{d}$ : comparison of means of MDA $\mu \mathrm{mol} / \mathrm{ml}$, TAC $\mathrm{mmol} / \mathrm{l}$ and SOD U/mg protein byolive pomace supplementation. Values followed by the same letter in the same column are not significantly different at $\mathrm{p} \leq$ 0.05 .

TABLE 5. Effect of feeding on supplemented biscuit with different olive pomace ratios on serum ALT and AST activities (U/L) as well as Total proteins $(\mathrm{g} / \mathrm{dl})$ and Albumin contents $(\mathrm{g} / \mathrm{dl})$ activity of hepatotoxic rats diabetic rat groups

\begin{tabular}{lccccc}
\hline Groups & $\begin{array}{c}\text { ALT } \\
(\mathbf{1 0 - 4 0 ~ U / L ) ~}\end{array}$ & $\begin{array}{c}\text { AST } \\
(\mathbf{1 0 - 3 7} \mathbf{U} / \mathbf{L})^{*}\end{array}$ & $\begin{array}{c}\text { Totalproteins } \\
(\mathbf{g} / \mathbf{d l})\end{array}$ & $\begin{array}{c}\text { Albumin } \\
(\mathbf{g} / \mathbf{d l})\end{array}$ & $\begin{array}{c}\text { Globulins } \\
(\mathbf{g} / \mathbf{d l})\end{array}$ \\
\hline Group 1 & 17.25 & 36.10 & 6.05 & 2.82 & 3.01 \\
Group 2 & $17.36^{\mathrm{b}}$ & $36.25^{\mathrm{a}}$ & $6.18^{\mathrm{e}}$ & $2.97^{\mathrm{a}}$ & $3.21^{\mathrm{e}}$ \\
Group 3 & $17.78^{\mathrm{b}}$ & $36.02^{\mathrm{a}}$ & $6.27^{\mathrm{d}}$ & $2.89^{\mathrm{b}}$ & $3.38^{\mathrm{d}}$ \\
Group 4 & $17.94^{\mathrm{b}}$ & $35.92^{\mathrm{b}}$ & $6.38^{\mathrm{c}}$ & $2.85^{\mathrm{b}}$ & $3.53^{\mathrm{c}}$ \\
Group 5 & $18.09^{\mathrm{a}}$ & $35.54^{\mathrm{b}}$ & $6.47^{\mathrm{b}}$ & $2.80^{\mathrm{b}}$ & $3.67^{\mathrm{b}}$ \\
Group 6 & $18.14^{\mathrm{a}}$ & $35.12^{\mathrm{b}}$ & $6.58^{\mathrm{a}}$ & $2.78^{\mathrm{b}}$ & $3.80^{\mathrm{a}}$ \\
\hline
\end{tabular}

${ }^{\bar{N}}$ Normal range.ALT or GPT: Glutamic pyruvic acid, AST or GOT: Glutamic oxalo- acetic acid

Each value is an average of five determinations.

Values followed by the same letter in column are not significantly different at $\mathrm{p} \leq 0.05$.

G1 - G6 as mentioned below of (Table 1).

Egypt. J. Sus. Agric. Sci . 43, No. 3 (2017) 
Effect of feeding on supplemented biscuit with different olive pomace ratios on total proteins, albumins and globulins activity

Likewise, data revealed that the total proteins in normal nutrition of rats was $6.05 \mathrm{~g} / \mathrm{dl}$, while they were $6.27,6.38,6.47$ and $6.58 \mathrm{~g} / \mathrm{dl}$, respectively when olive pomace at ratios $(2.5,5,7.5$ and $10 \%)$ was supplemented in biscuit. The same table revealed that the total albumins in normal nutrition of rats was $2.82 \mathrm{~g} / \mathrm{dl}$, while the treatments by olive pomace at ratio of $(2.5,5,7.5$ and $10 \%)$, decreased them to $2.89,2.85,2.80 \mathrm{~g} / \mathrm{dl}$, respectively. From Table 3, it was notified that the total Globulins rised from 3.01 in normal nutrition of rats to reach $3.80 \mathrm{~g} /$ $\mathrm{dl}$ after treatment by olive pomace at ratio $(10 \%)$, followed by the total Globulins after the treatments by olive pomace at ratio $(7.5,5$ and $2.5 \%)$, which were $3.67,3.53$ and $3.38 \mathrm{~g} / \mathrm{dl}$, respectively. Obtained data are in agreement with those by Abdel-Samee et al. (2008), who found that effect of nutritional Olive pomace treatments on biochemical constituents (ALT, AST, total protein, albumin and globulin), in heat stressed sheep in relation, which were $15.5 \mathrm{U} / \mathrm{L}, 39.0 \mathrm{U} / \mathrm{L}, 6.24 \mathrm{mg} / \mathrm{dl}, 3.44 \mathrm{mg} / \mathrm{dland}$ $2.80 \mathrm{mg} / \mathrm{dl}$, respectively. As compared with control sheep, which were $13.8 \mathrm{U} / \mathrm{L}, 34.9 \mathrm{U} / \mathrm{L}, 5.31 \mathrm{mg} / \mathrm{dl}$, $2.83 \mathrm{mg} / \mathrm{dl}$ and $2.48 \mathrm{mg} / \mathrm{dl}$, respectively.Mahmoud et al., (2013), Who found the of supplementation of broiler diets with olive oil (1\%), were on total protein, albumin, globulin, ALT, and AST, which were $4.45 \mathrm{~g} / \mathrm{dl}, \quad 1.69 \mathrm{~g} / \mathrm{dl}, 2.76 \mathrm{~g} / \mathrm{dl}, 7.58 \mathrm{U} / \mathrm{L}$ and $59.79 \mathrm{U} / \mathrm{L}$, after 42 days, respectively. As compared with control, which were $4.02 \mathrm{~g} / \mathrm{dl}, 1.69 \mathrm{~g} / \mathrm{dl}, 2.33 \mathrm{~g} /$ $\mathrm{dl}, 9.42 \mathrm{U} / \mathrm{L}$ and $64.11 \mathrm{U} / \mathrm{L}$, respectively. Attained data agreeed with those of Mohammed and Youssef (2015), who found an effect of olive cake ratio with or without citric acid supplementation on (total protein, albumin, globulin, AST and ALT) of laying hens, which were $6.53 \mathrm{~g} / \mathrm{dl}, 4.34 \mathrm{~g} / \mathrm{dl}, 3.19 \mathrm{~g} / \mathrm{dl}$, $56.2 \mathrm{U} / \mathrm{L}$ and $64.4 \mathrm{U} / \mathrm{L}$, at a ratio $10 \%$, respectively as compared with control hens, which were $6.76 \mathrm{~g} /$ $\mathrm{dl}, 3.46 \mathrm{~g} / \mathrm{dl}, \quad 3.30 \mathrm{~g} / \mathrm{dl}, \quad 53.5 \mathrm{U} / \mathrm{L}$ and $64.0 \mathrm{U} / \mathrm{L}$, respectively.

\section{Effect of feeding on supplemented biscuit with} different olive pomace ratios on kidney functions

The results of kidney functions (urea and creatinine) of normal control and diabetic rats at the end of experimental period were recorded in Table 6 . It can be observed that the serum creatinine in normal nutrition of rats and after treatment by olive pomace at ratio $(2.5 \%)$, was 0.85 and $0.58 \mathrm{mg} / \mathrm{dl}$, respectively. Similarly, the treatment of biscuit with olive pomace at ratio $(5,7.5$ and $10 \%)$ raised to $0.59,0.59$ and $0.59 \mathrm{mg} /$ $\mathrm{dl}$, respectively. Likewise, after the treatment of biscuit supplemented with olive pomace at ratio $(2.5,5,7.5$ and $10 \%$ ), they were $75.91,76.15,76.81$ and $77.64 \mathrm{mg} /$ $\mathrm{dl}$, respectively as compared to normal nutrition of rats, that was $75.45 \mathrm{mg} / \mathrm{dl}$.This finding was in the same line with Abdel-Samee et al. (2008), who found an effect of nutritional treatments with olive on Kidney functions (Urea and Creatinine), in heat stressed sheep in relation, which were $18.3 \mathrm{mg} / \mathrm{dl}$ and $1.22 \mathrm{mg} /$ $\mathrm{dl}$, respectively as compared to control sheep, which were $15.5 \mathrm{mg} / \mathrm{dl}$ and $1.22 \mathrm{mg} / \mathrm{dl}$, respectively. Bawazir (2011) found the effect of chronic oral administration of extra virgin olive oil ( $7.5 \mathrm{mg} / \mathrm{kg}$ b.wt.) on urea and creatinine of male albino rat, which were $42.5(\mathrm{mg} /$ dI) and $0.383(\mathrm{mg} / \mathrm{dI})$, after 4 weeks, respectively as compared with control rats, which were $97.33(\mathrm{mg} / \mathrm{dI})$ and $0.417(\mathrm{mg} / \mathrm{dI})$, respectively.

The effect of feeding on supplemented biscuit with different olive pomace ratios on some serum lipid profile

Effect on total cholesterol and triglycerides

From Table 7, it can be noticed that total cholesterol decreased with increasing the treatment of supplementation of olive pomace in rats nutrition percentage $10 \%$ which was $2.44 \mathrm{mg} / \mathrm{dl}$. While, the decreased supplementation of olive pomace in rats nutrition at treatments percentages $2.5,5$ and $7.5 \%$,they were $3.21,2.75$ and $2.94 \mathrm{mg} / \mathrm{dl}$, respectively compared to normal nutrition of rats which was, $3.43 \mathrm{mg} / \mathrm{dl}$. In Table 7 , we can observe that triglycerides increased by decreasing the treatment of supplementation of olive pomace rats nutrition percentage to 7.5 and $10 \%$, to be 97.5 and $97.3 \mathrm{mg} / \mathrm{dl}$. While, the decreased supplementation ratio of olive pomace in rats nutrition at treatments percentages 2.5 and $5 \%$, they were 98.6 and $98.2 \mathrm{mg} / \mathrm{dl}$, respectively compared to normal nutrition of rats, it was, $98.9 \mathrm{mg} / \mathrm{dl}$.

Effect on HDL, LDL and $v L D L$-cholesterol

There is a relationship between the level of HDL-cholesterol and hypertriglyceridemia, hypercholesterolemia and lipoprotein cholesterol heart disease, the high level of HDL-cholesterol decreased the evidence of atherosclerosis. Data in Table 7, also show that treatment of supplementation of olive pomace in rats nutrition led to a gradual increase of serum HDL. Raising both treatments of the experiment caused an increase in serum HDL, which reached $37.91 \mathrm{mg} /$ $\mathrm{dl}$, of olive pomace supplementation in rats nutrition at percentage $10 \%$, While feeding rats on biscuits supplemented with olive pomace at Egypt. J. Sus. Agric. Sci . 43, No. 3 (2017) 
2.5, 5 and $7.5 \%$, gave serum HDL values 63.95, 37.11 and $37.66 \mathrm{mg} / \mathrm{dl}$, respectively compared to normal nutrition of rats, it was $36.38 \mathrm{mg} / \mathrm{dl}$. The data in Table 7, showed similar effect on serum LDL. Raising both treatments of the experiment caused a decrease in serum LDL, which reached $13.40 \mathrm{mg} / \mathrm{dl}$, with supplementation of olive pomace in rats nutrition at percentage $10 \%$, While, the decrease of supplementation of olive pomace in rats nutrition to percentages $2.5,5$ and $7.5 \%$, it reached $13.29,13.32$ and $13.35 \mathrm{mg} / \mathrm{dl}$, respectively compared to normal nutrition of rats, which was $13.25 \mathrm{mg} / \mathrm{dl}$. Data for vLDL values as a result of treatments of supplementation of olive pomace in rats nutrition, increased from $19.2 \mathrm{mg} /$ dl of normal nutrition to $19.4,19.6,19.69$ and $19.72 \mathrm{mg} / \mathrm{dl}$, at treatments $2.5,5,7.5$ and $10 \%$ of olive pomace in rats nutrition when supplemented in prepared biscuit, respectively. Obtained data are in agreement with those by Kim et al. (2014) who found an effect of Olea europea-ethyl acetate (Oleaceae) fruit pomace (Oleaceae) extract on plasma lipid levels (TC, TG, HDL and LDL), of rats after administering a dose of $100 \mathrm{mg} / \mathrm{kg}$, to be $5.45,0.65,8.74$ and $0.59(\mathrm{mM})$, respectively. While, plasma lipid levels of normal control were1.73, $0.70,0.40$ and $0.91(\mathrm{mM})$, respectively. Also, Amal et al. (2012) found that they were affected by the experimental diets on total cholesterol, Triglycerides, HDL-cholesterol, LDL-cholesterol and VLDL of male New - zealand white rabbits, were $64.67,52.90,39.50,14.59$ and $10.58 \mathrm{mg}$ / $\mathrm{dl}$, at a ratio $1.5 \%$, respectively as compared to $0 \%$, which were $69.33,66.10,31.27,24.84$ and $13.22 \mathrm{mg} / \mathrm{dl}$, respectively. Mahmoud et al. (2013) found the effect of supplementation of broiler diets with olive oil (1\%), on Triglyceride, HDLcholesterol and LDL-cholesterol, which were

TABLE 6. Effect of feeding on supplemented biscuit with different olive pomace ratios on kidney functions $(\mathrm{mg} / \mathrm{dl})$ of the experimental diabetic rat groups

\begin{tabular}{|c|c|c|}
\hline Groups & $\begin{array}{c}\text { Urea }(\mathrm{mg} / \mathrm{dl}) \\
(10-50 \mathrm{mg} / \mathrm{dl})^{*}\end{array}$ & $\begin{array}{c}\text { Creatinine }(\mathrm{mg} / \mathrm{dl}) \\
(0.5-1.5 \mathrm{mg} / \mathrm{dl}) *\end{array}$ \\
\hline Group 1 & $34.25^{\mathrm{e}}$ & $0.54^{\mathrm{d}}$ \\
\hline Group 2 & $39.45^{\mathrm{a}}$ & $0.60^{\mathrm{a}}$ \\
\hline Group 3 & $35.91^{\mathrm{d}}$ & $0.58^{\mathrm{c}}$ \\
\hline Group 4 & $36.15^{\mathrm{c}}$ & $0.59^{\mathrm{b}}$ \\
\hline Group 5 & $36.81^{\mathrm{c}}$ & $0.59^{\mathrm{b}}$ \\
\hline Group 6 & $37.64^{b}$ & $0.59^{b}$ \\
\hline
\end{tabular}

*Normal range

Each value is an average of five determinations.

Values followed by the same letter in column are not significantly different at $\mathrm{p} \leq 0.05$.

G1 - G6 as mentioned blow (Table 2).

TABLE 7. Effect of feeding on supplemented biscuit with different olive pomace ratios on some serum lipid profile ( $\mathrm{mg} / \mathrm{dl})$ of the experimental diabetic rat groups

\begin{tabular}{lcccccc}
\hline Groups & $\begin{array}{c}\text { TC (mg/d) } \\
(\mathbf{1 4 0 - 2 0 0 ) *}\end{array}$ & $\begin{array}{c}\text { HDL-c (mg/dl) } \\
\mathbf{( 4 1 - 7 5 ) ^ { * }}\end{array}$ & AI & $\begin{array}{c}\text { LDL-c } \\
(\mathbf{m g} / \mathbf{d l})\end{array}$ & $\begin{array}{c}\text { TG }(\mathbf{m g} / \mathbf{d l}) \\
(\mathbf{6 0 - 1 6 5})^{*}\end{array}$ & $\begin{array}{c}\text { vLDL-c } \\
(\mathbf{m g} / \mathbf{d l})\end{array}$ \\
\hline Group 1 & $98.2^{\mathrm{b}}$ & $36.30^{\mathrm{c}}$ & $1.71^{\mathrm{a}}$ & $13.20^{\mathrm{c}}$ & $19.10^{\mathrm{c}}$ & $3.25^{\mathrm{b}}$ \\
Group 2 & $8.9^{\mathrm{a}}$ & $36.38^{\mathrm{b}}$ & $1.72^{\mathrm{a}}$ & $13.25^{\mathrm{b}}$ & $19.20^{\mathrm{c}}$ & $3.43^{\mathrm{a}}$ \\
Group 3 & $98.6^{\mathrm{a}}$ & $36.95^{\mathrm{b}}$ & $1.67^{\mathrm{b}}$ & $13.29^{\mathrm{b}}$ & $19.40^{\mathrm{b}}$ & $3.21^{\mathrm{b}}$ \\
Group 4 & $98.2^{\mathrm{b}}$ & $37.11^{\mathrm{a}}$ & $1.65^{\mathrm{b}}$ & $13.32^{\mathrm{a}}$ & $19.60^{\mathrm{b}}$ & $2.95^{\mathrm{c}}$ \\
Group 5 & $97.5^{\mathrm{c}}$ & $37.66^{\mathrm{a}}$ & $1.59^{\mathrm{c}}$ & $13.35^{\mathrm{b}}$ & $19.69^{\mathrm{a}}$ & $2.74^{\mathrm{c}}$ \\
Group 6 & $97.3^{\mathrm{c}}$ & $37.91^{\mathrm{a}}$ & $1.57^{\mathrm{c}}$ & $13.40^{\mathrm{a}}$ & $19.72^{\mathrm{a}}$ & $2.44^{\mathrm{d}}$ \\
\hline
\end{tabular}

* Normal range.

TC: Cholesterol, HDL-c: High density lipoprotein, LDL-c: Low density lipoprotein, TG: triglycerides, AI: Atherogenic index, TL: Total lipids and vLDL-c: very low density lipoprotein

Each value is an average of five determinations. Mean values in each column having different superscript $(a, b, c, .$.$) are significant at \mathrm{p}<0.05$ by different and vice versa.

G1 - G6 as mentioned below of (Table 1).

Egypt. J. Sus. Agric. Sci . 43, No. 3 (2017) 
$50.25 \mathrm{mg} / \mathrm{dl}, 79.32 \mathrm{mg} / \mathrm{dl}$ and $38.83 \mathrm{mg} / \mathrm{dl}$, after 42 days, respectively as compared with control, which were $54.36 \mathrm{~g} / \mathrm{dl}, 88.52 \mathrm{mg} / \mathrm{dl}$ and $42.19 \mathrm{~g} /$ $\mathrm{dl}$, respectively. This finding was in the same line of Ismail and Abd - Elgawad (2010) who found an effect of anna apple pomace powder on total cholesterol, Triglycerides, HDL-cholesterol, LDL-cholesterol and VLDL, of diabetic rats, which were $130.55,59.70,39.39,97.21$ and $11.94 \mathrm{mg} / \mathrm{dl}$, at ratio of $2.5 \%$, respectively. compared to control rats, which were 81.37, $43.51,47.20,25.47$ and $8.70 \mathrm{mg} / \mathrm{dl}$, respectively.

Effect of supplementation of biscuit with olive pomace on haematological parameters

The complete blood count (CBC) was used as a broad screening test to check such disorders as anemia, infection and many other diseases. It is actually a panel of tests that examines different parts of the blood, which play an important role in metabolism and important indicators of health in both human and animals (Bain et al., 2006).

The complete blood count (CBC) includes the following tests:

Effect on HB, RBCs, PCV, MCV and MCHC:

Data in Table 8 conveyed that the haemoglobin level $(\mathrm{Hb})$, in normal nutrition of rats, which was $10.19 \mathrm{~g} / \mathrm{dl}$ and increased high percentage to 11.75 , 11.98 and $12.07 \mathrm{~g} / \mathrm{dl}$, at treatments $5,7.5$ and $10 \%$ of olive pomace when supplemented to biscuit. While, the effect of supplementation olive pomace attribution $2.5 \%$ in nutrition of rats increased haemoglobin level to $10.30 \mathrm{~g} / \mathrm{dl}$, respectively. From the same table, it was clear that the total red blood cells (RBCs) rised from $5.19 \times 10^{6} / \mu \mathrm{L}$ for normal nutrition of rats to $5.21,5.79,5.95$ and $6.09 \times 10^{6} / \mu \mathrm{L}$ after treatment of olive pomace when supplemented to biscuit percentage 2.5, 5, 7.5 and $10 \%$, respectively.

The same table showed that the total packed cell volume (PCV) of control negative group, was $38.17 \%$ which increased to $39.00,40.33$, 41.09 and $42.17 \%$, after feeding on biscuit supplemented with $2.5,5,7.5$ and $10 \%$ olive pomace, respectively. The data revealed that the total mean corpuscular volume (MCV) of normal nutrition of rats, was $57.04 \mu \mathrm{m}^{3}$ which increased to $57.95,58.44,58.98$ and $59.48 \mu \mathrm{m}^{3}$, feeding on biscuit supplemented with $2.5,5,7.5$ and $10 \%$ olive pomace, respectively. In the same table, results showed that the total mean corpuscular hemoglobin ratio (MCHC) rised from 33.11/ $\mathrm{dl}$ for normal nutrition of rats to $34.09,34.93$, 35.03 and $35.96 \mathrm{~g} / \mathrm{dl}$, after feeding on biscuit supplemented with $2.5,5,7.5$ and $10 \%$ olive pomace, respectively.

\section{Effect on Plt, MPV, PCT and PDW}

Data in Table 9, reveal that the platelet blood (Plt) level in normal nutrition of rats, was $1109 \times 10^{3} / \mu \mathrm{l}$ and increased with high percentage to 1209 and $1281 \times 10^{3} / \mu \mathrm{L}$, for rats fed on biscuit supplemented with 7.5 and $10 \%$ olive pomace, respectively. While, the effect of supplementation with olive pomace attribution 2.5 and $5 \%$ in rats nutrition increasing platelet level to 1123 and $1173 \times 10^{3} / \mu \mathrm{L}$, respectively. The table showed that the mean platelet volume (MPV) rised from $9.2 \mu \mathrm{m}^{3}$ for normal nutrition of rats to reach to $9.3 \mu \mathrm{m}^{3}$ after feeding on biscuit supplemented with $5,7.5$ and $10 \%$ olive pomace, respectively. However, the effect of supplementation with olive pomace attribution $2.5 \%$ in rat nutrition on (MPV), was $9.2 \mu \mathrm{m}^{3}$, did not have any effect. The same table showed that the platelets hematocrit

TABLE 8. Effect of Supplementation of olive pomace for biscuit on haematological parameters of the experimental diabetic rat groups

\begin{tabular}{llllll}
\hline Groups & $\mathbf{H b}(\mathbf{g} / \mathbf{d l})$ & RBCs $(\mathbf{1 0} / \boldsymbol{\mu l})$ & $\mathbf{P C V}(\%)$ & $\mathbf{M C V}(\boldsymbol{\mu m} \mathbf{m})$ & $\mathbf{M C H C}(\mathbf{g} / \mathbf{d l})$ \\
\hline Group 1 & $10.30^{\mathrm{c}}$ & $5.20^{\mathrm{c}}$ & $40.35^{\mathrm{b}}$ & $57.99^{\mathrm{c}}$ & $33.15^{\mathrm{c}}$ \\
Group 2 & $10.19^{\mathrm{c}}$ & $5.19^{\mathrm{c}}$ & $38.17^{\mathrm{e}}$ & $57.04^{\mathrm{d}}$ & $33.11^{\mathrm{c}}$ \\
Group 3 & $10.30^{\mathrm{c}}$ & $5.21^{\mathrm{c}}$ & $39.00^{\mathrm{d}}$ & $57.95^{\mathrm{c}}$ & $34.09^{\mathrm{b}}$ \\
Group 4 & $11.75^{\mathrm{b}}$ & $5.79^{\mathrm{b}}$ & $40.33^{\mathrm{c}}$ & $58.44^{\mathrm{b}}$ & $34.93^{\mathrm{b}}$ \\
Group 5 & $11.98^{\mathrm{b}}$ & $5.95^{\mathrm{b}}$ & $41.09^{\mathrm{b}}$ & $58.98^{\mathrm{b}}$ & $35.03^{\mathrm{a}}$ \\
Group6 & $12.07^{\mathrm{a}}$ & $6.09^{\mathrm{a}}$ & $42.17^{\mathrm{a}}$ & $59.48^{\mathrm{a}}$ & $35.96^{\mathrm{a}}$ \\
\hline
\end{tabular}

Hemoglobin $(\mathrm{Hb})$, red blood cells count (RBC), packed cell volume (PCV), mean corpuscular volume (MCV), mean corpuscular hemoglobin ratio (MCHC). Each value is an average of five determinations. Mean values in each column having different superscript $(a, b, c, .$.$) are significant at \mathrm{p}<0.05$ by different and vice versa.

G1 - G6 as mentioned below of (Table 1). 
value (PCT) in normal nutrition of rats was $8.1 \%$, which rised at high percentage to 8.36 and $8.42 \%$ after treatment with olive pomace at percentage 7.5 and $10 \%$, when supplemented to biscuit of rat nutrition, respectively. While, the effect of supplementation with olive pomace attribution 2.5 and $5 \%$ in nutrition of rats on (PCT) increased to $8.2 \%$ and 8.2 , respectively. On the other hand, Table 9 show that the total platelet distribution width (PDW) values as a result of treatment of supplementation of olive pomacein rats nutrition, increased to $12.2,12.6,12.6$ and $12.7 \%$, for rats fed on biscuit supplemented with 2.5, 5, 7.5 and $10 \%$ olive pomace, respectively. As compared with normal nutrition of rats, which was $12.2 \%$.

\section{Effect on WBCs, Lym, Mono and GRA}

Data in Table 10 reveal that white blood cells (WBCs) level in normal and treatment olive pomace percentage $2.5 \%$, of rat nutrition, was $11.23 \times 10^{3} / \mu \mathrm{L}$. and increased to $11.46,11.83$ and $11.89 \times 10^{3} / \mu \mathrm{L}$, at treatment with olive pomace percentage 5, 7.5 and $10 \%$, respectively when supplemented in biscuit. From Table 9, it was showed that the levels of Lymphocytes (Lym) increased from $5.35 \times \mu \mathrm{m}^{3}$ for normal nutrition of rats to reach $5.41,5.51,6.10$ and $6.51 \times 10^{3} / \mu \mathrm{L}$, for rats fed on biscuit supplemented with $2.5,5,7.5$ and $10 \%$ olive pomace, respectively.

The data revealed that the Monocytes (Mono) value of normal nutrition of rats was $0.45 \%$ which higher to 0.52 and $0.55 \%$ for rats feed on biscuit supplemented with 7.5 and $10 \%$ olive pomace, respectively followed by groups fed on biscuit supplemented with 2.5 and $5 \%$ olive pomace, respectively. On the other hand Table 9 showed that the Granulocytes (GRA) of normal nutrition of rats, was $38.0 \%$ while after supplementation with olive pomace attribution 2.5, 5, 7.5 and $10 \%$, of nutrition of rats on (GRA) they were 38.5, 39.0 and $39.7 \%$, respectively.

This results agreed with Mahmoud et al. (2013), Nandakumaran et al. (2014) and Nadir et al. (2016) who found the effects of oleuropein on hematological analysis including ( $\mathrm{RBCs}, \mathrm{Hb}$, PCV and PLTs) in plasma of experimental rats, which were $7.44\left(\times 10^{6} / \mu \mathrm{L}\right), 14.2(\mathrm{~g} / \mathrm{dl}), 44.25 \%$ and $434.00\left(\times 10^{3} / \mu \mathrm{L}\right)$, at treatment $10 \mathrm{mg} / \mathrm{kg}$, respectively compared to those of normal control rats, which were $6.75(\mathrm{x} 106 / \mu \mathrm{L}), 12.82(\mathrm{~g} / \mathrm{dl})$, $40.35 \%$ and $456.13(\mathrm{x} 103 / \mu \mathrm{L})$, at treatment $10 \mathrm{mg} /$ $\mathrm{kg}$, respectively.

\section{Conclusion}

The effects of biscuit supplementation with olive pomace in ratios $2.5,5,7.5$ and $10 \%$ in nutrition of rats are increasing body weight and improvement of blood biochemical of rats. The comparison of the results of olive pomace with leaves, fruits and oil gives an importance to olive pomace as nutritional and healthy formulas.

TABLE 9. Effect of supplementation of olive pomace for biscuit on plt deferential of the experimental diabetic rat groups

\begin{tabular}{lcccc}
\hline Groups & PIt $(\mathbf{1 0 3} / \boldsymbol{\mu l})$ & MPV $\left(\boldsymbol{\mu \mathbf { m } ^ { 3 } )}\right.$ & PCT $(\mathbf{\%})$ & PDW $(\mathbf{\%})$ \\
\hline Group 1 & $1120^{\mathrm{b}}$ & $9.3^{\mathrm{a}}$ & $8.3^{\mathrm{b}}$ & $12.5^{\mathrm{c}}$ \\
Group 2 & $1109^{\mathrm{c}}$ & $9.2^{\mathrm{b}}$ & $8.1^{\mathrm{d}}$ & $12.2^{\mathrm{d}}$ \\
Group 3 & $1123^{\mathrm{b}}$ & $9.2^{\mathrm{b}}$ & $8.2^{\mathrm{c}}$ & $12.4^{\mathrm{c}}$ \\
Group 4 & $1172^{\mathrm{b}}$ & $9.3^{\mathrm{a}}$ & $8.2^{\mathrm{c}}$ & $12.6^{\mathrm{b}}$ \\
Group 5 & $1209^{\mathrm{a}}$ & $8.3^{\mathrm{b}}$ & $12.6^{\mathrm{b}}$ \\
Group 6 & $1281^{\mathrm{a}}$ & $9.3^{\mathrm{a}}$ & $8.4^{\mathrm{a}}$ & $12.7^{\mathrm{a}}$ \\
\hline Platelets count (Plt), mean platelet volume (MPV), platelets hematocrit (PCT), platelet distribution width (PDW).
\end{tabular}

Platelets count (Plt), mean platelet volume (MPV), platelets hematocrit (PCT), platelet distribution width (PDW).

TABLE 10. Effect of supplementation of olive pomace for biscuit on WBCs deferential of the experimental diabetic rat groups

\begin{tabular}{|c|c|c|c|c|}
\hline Groups & WBC $\left(10^{3} / \mu \mathrm{l}\right)$ & $\operatorname{Lym}\left(10^{3} / \mu \mathrm{l}\right)$ & Mono (\%) & GRA (\%) \\
\hline Group 1 & 11.24 & 5.37 & 0.47 & 38.4 \\
\hline Group 2 & $11.23^{\mathrm{d}}$ & $5.35^{\mathrm{e}}$ & $0.45^{\mathrm{b}}$ & $38.0^{\mathrm{b}}$ \\
\hline Group 3 & $11.23^{\mathrm{d}}$ & $5.41^{\mathrm{d}}$ & $0.46^{\mathrm{b}}$ & $38.5^{\mathrm{b}}$ \\
\hline Group 4 & $11.46^{\mathrm{c}}$ & $5.51^{\mathrm{c}}$ & $0.49^{\mathrm{b}}$ & $38.8^{\mathrm{b}}$ \\
\hline Group 5 & $11.83^{\mathrm{b}}$ & $6.10^{\mathrm{b}}$ & $0.52^{\mathrm{a}}$ & $39.0^{\mathrm{a}}$ \\
\hline Group 6 & $11.89^{\mathrm{a}}$ & $6.51^{\mathrm{a}}$ & $0.55^{\mathrm{a}}$ & $39.7^{\mathrm{a}}$ \\
\hline
\end{tabular}

White blood cells count (WBC), Lymphocytes (LYM), Monocytes (MON) and Granulocytes (GRA). 


\section{References}

Abdel-Samee, A. M.; Abd-Alla, O. A. and EL-Adawy, S. A. (2008) Nutritional treatments for alleviation of heat stress in Awassi sheep using acacia and olive Pomace in Subtropics.Egypt. J. Comp. Path. \& Clinic.Path., 21, 466- 477.

Allam, H.; Abdelazem, M. A.; Halla, S. F. and Abdalla, H. (2016) Some hemato- biochemical, bacteriological and pathological effects of olive pomace leaf extract in chickens. International $J$. Basic and Applied Sciences, 5 (2), 99-104.

Amal, M.F.; Azoz, A.A.; Afaf, H.Z. and Basyony, M. (2012) Effects of pomegranate peels as antioxidant supplementation on digestibility, blood biochemical and rabbit semen quality. Egyptian J. Nutrition and Feeds, 15 (2), 343-354.

Andallu, B. and Vardacharyulu, N. (2001) Effect of mulberry leaves on diabetes. Int. J. Diab. Dev. Countries, 21, 147-151.

Bain, B. J. (2006) Blood Cells (a Practical guide), 4th edition. Blackwell.

Bawazir, A. E. (2011) Chronic effect of olive oil on some neurotransmitter contents in different brain regions and physiological, histological structure of liver and kidney of male albino rats. World Journal of Neuroscience., 1, 31-37.

Benzie, I. F. and Strain, J. J. (1996) The ferric reducing ability of plasma (FRAP) as a measure of "antioxidant power": the fRAP assay". Analytical Biochemistry, 239 (1): 70-6.

Costat Program, Version 6.311 (2005) Cohort software, 798 lighthouse ave. PMB 320, Monterey, CA, 3940, USA. http://www.cohort.com.

Das, K.; Samanta, L. and Chainy, G. B. N. (2000) A modified spectrophotometric assay of superoxide dismutase using nitrite formation by superoxide radicals.Ind J. Biochem.Biophys; 37, 201-204.

Deepa, D. S; Subhas, D. G; Shishir, R. S. and Preethi, B. (2012) Estimation of serum malondialdehyde in potentially malignant disorders and postantioxidant treated patients.Contemporary Clinical Dentistry; 3, 448-451.

Doumas, B.T.; Westsom, W. A. and Biggs, H. G. (1971) Albumin standards and measurement of serum albumin with bronocresol.Green.Clin Chem. Acta, 31: 87 .

Duncan, D. B. (1955) Multiple range tests and multiple F test. Biometrics, 11: 1-42.
Eskander, E. F. and Jun, H. W., (1995) Hypoglycemic and Hyperinsulinemic effect on some Egyptain herbs used for the treatment of diabeticmellitus (typeII) in rats. Egypt. J. Pharma Sci., 36, 1-6: 331342.

Esmerino, A. L. (1998) Blood glucose determination in normal and alloxan-diabetic rats after administration of local anesthetics containing vaso constrictors Braz Dent J. 9 (1): 33-37, ISSN 0103-6440. (C. F. Abd El-Hady, S. R. (2003). Ph. D. Thesis, Faculty of Agriculture, Tanta Univ. Egypt).

Goulas, V. and George, A.M. (2011) Towards an efficient protocol for the determination of triterpenic acids in olive fruit: A comparative study of drying and extraction methods. Phytochem. Anal; 23, 444-449.

Hasegawa, R.; Chujo, T.;Sai-Kato K.; Umemura, T.; Tanimura, A. and Kurokawa Y. (1995) Preventive effects of green tea against liver oxidative DNA damage and hepatotoxicity in rats treated with 2-nitropropane. Food Chem Toxicol. 33, 961-965.

Henry, R. J. (1964) Clinical chemistry principles and techincs.Haper\& Row Publisher. New York.

Ismail, R. S. A. and Abd El-Gawad, S. H. (2010) Potential effect of egyptionennaepplepomace (mion and lipid profile of diabetic rats. World $J$. Dairy and Food Science., 5 (1), 58-66.

Jaffẻ, M. (1986) Determination of ceratinine-kineticin serum, plasma or urine.Zischerphysiol \& Chem., 10, 391.

Kawase, M.; Hashimoto, M.; Hosads, H.; Morita and Hosono, A. (2000) Effect of administration of fermented milk containing whey protein concentrates to rats and healthy men on serum lipids and blood pressure. J. Diary Sci., 38, 255263.

Kim, M. and Shin, H.K. (1998) The water Soluble Extract of Chicory influences serum and liver lipid ratios, Cecal short chain fatty acid ratios and fecal lipid extraction in rats. J. Nutr., 128 (1), 17311736.

Kim, M.S., Sushruta, K.; Soo-Jin, S.; Sang-Rin, L.; Yong-Dae, P.; Kyung-Ae, L.; Tae-Kyu, P. and Hyun, K. (2014) Oleaeuropaealinn (oleaceae) fruit pomace exhibits hypocholes-terolemic and hepatoprotective effects via regulation of peroxisome proliferationactivated receptor alpha in high-fat diet-fed rats. Tropical J. of Pharmacentical Research., 13 (1), 31-39.

Koyama, E.; Sakai, N.; Ohori, Y.; Kitazawa, K.; Izawa, O.; Kakegawa, K., et al., (2003) Absorption and

Egypt. J. Sus. Agric. Sci . 43, No. 3 (2017) 
metabolism of glycosidic sweeteners of stevia mixture and their aglycone, steviol, in rats and humans. Food ChemToxicol 41(6), 875-883.

Mahmoud, R. E.; Ibrahim, D. and Badawi, M. E. (2013) Effect of supplementation of broiler diets with guava leaves and/or olive oil on growth, meat composition, blood metabolites and Immune response.Benha Veterinary Medical J., 25, 23-32.

Matthews, H.B.; Lucier, G.W. and Fisher, K. D. (1990) Medicinal herbs in the United States: research needs. Environ Health Perspect. 107, 773-778.

Melis, M.S. (1995) Chronic administration of aqueous extract of Stevia rebaudiana in rats, renal effects. $J$. Ethnopharmacol. 47, 129-134.

Mohammed, A.A. and Youssef, A. A. (2015) Effect of citric acid on the utilization of olive cake diets for laying hens. Italian Journal of Animal Science, 14, 3966, 394-402.

Molina, A. E.; Yànez, R. D. R.; Moumen, A. and Martìn, G. A. I. (2003) Chemical composition and nitrogen availability for goats and sheep of some olive by-products. Small Ruminant Research, 49, 329-336.

Nadir, M, Q.; Khabat, A.A. and Suhailah, W.Q. (2016) Antidiabetic Effect of Oleuropein from Oleaeuropaea Leaf against Alloxan Induced Type 1 Diabetic in Rats. Braz. Arch. Biol. Technol., 59, $1-10$.

Nakul, A. D.; Sudaka, I.; Ferrero, C.; Starck, B. and Bayle, J. (2003) Evaluation of the Sysmex Xe2100® hematology analyzer in hospital use. J. Clin Lab Anal, 17: 113-123.

Nandakumaran, M.; Baydaa, A; Mariam, A. and Majed, A. (2014) Effect of Olive Oil Administration on Certain Hematologic and Metabolic Parameters in Pregnant Rats. Int. J. Pure App. Biosci. 2 (4), 93-99.

Nnam, N. M. and Nwokocha, M. O. (2003) Chemical and organoleptic evaluation of biscuits made from mixtures of hungry rice, acha (Digitariaexilis) sesame; (Sesamumindicum); and breadfruit (Artocarpusatilis) flours. Plant Foods for Human Nutrition, 58,1-11.

Pal, R.K. and Manoj, J. (2011) Hepatoprotective activity of alcoholic and aqueous extracts of fruits of Luffa cylindrical Linn in rats. Ann Biol Res. 2 (1), 132-141.

Patel, R. K.; Patel, M. M.; Patel, M.P., Kanzaria, N. R.; Vaghela, K. R. and Patel N.J. (2008) Hepatoprotective activity of Moringaoleifera L. fruit on isolated rat hepatocytes. Pharmacogn Mag. 4,118-123.

Egypt. J. Sus. Agric. Sci . 43, No. 3 (2017)
Patton, C.J. and Crouch, S.R. (1977) Enzymatic determination of urea.Anal.Chem; 49, 464-469.

Samuel, A.J., Mohan, S., Chellappan, D.K., Kalusalingam, A. and Ariamuthu, S. (2012) Hibiscus vitifolius (L.) root extracts shows potent protective action against anti-tubercular drug induced hepatotoxicity. J. Ethnopharmacol. 141(1): 396-402.

Sohair, Y. S.; Sawiress, F.A., Tony, M.A., Hassanin, A.M; Khattab, M.A. and Bakeer, M.R. (2015) Protective Role of Some Feed Additives against Dizocelpine Induced Oxidative Stress in Testes of Rabbit Bucks. Journal of Agricultural Science, 7, 239-252.

Sravanthi, J. and Rao, S. G. (2014) Antioxidative studies in Olive pomace Lam. Annals of Phytomedicine, $\mathbf{3}$ (2), 101-105.

Trinder, P. (1969) Enzymatic determination of triglycerides in serum. Ann. Clin. Biochem. 6, 2427.

Varley, H.; Gewenlock, A. and Bell, M. (1980) Practical Biochemistry, (1), $5^{\text {th }}$ ed. William Heinemann Medical Books, 1td, London, 741- 897.

Wardlaw, G. M. and Snook, J. T. (1990) Effect of diets high in butter, corn oil, or high-oleic and sunflower oil on serum lipids and apolipoproteins in men. Am. J. Clin. Nutr., 51, 815-821.

Wolf, P.L. (1999) Biochemical diagnosis of liver diseases.Indian J. Clin Biochem. 14 (1), 59-90.

Zarei1, M., Ehsanin M. and Torki, M. (2011) Productive performance of laying hens fed wheat-based diets included olive pulp with or without a commercial enzyme product. African Journal of Biotechnology, 10 (20), 4303-4312.

(Received: 20/ 8/ 2017; accepted: 31/10/2017) 


\section{تفل الزيتون على فئران مصابة بمرض السكر

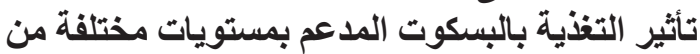

محمد فرحات القطب،سعد الله محمد صالح وسمير يوسف السناط الزباط

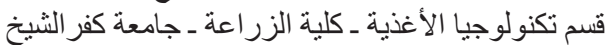

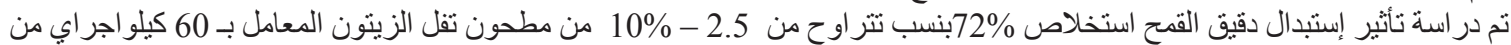

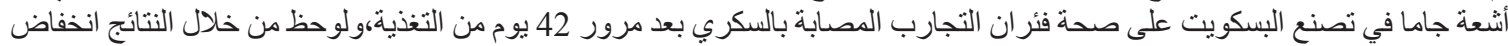

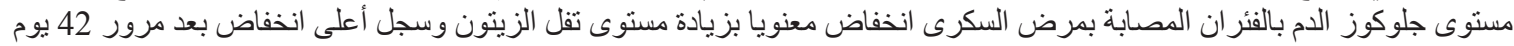

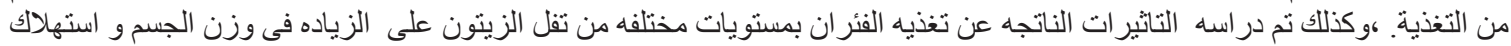

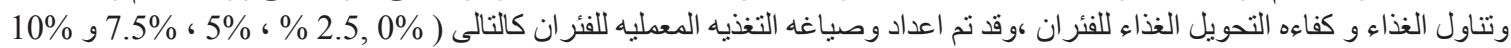

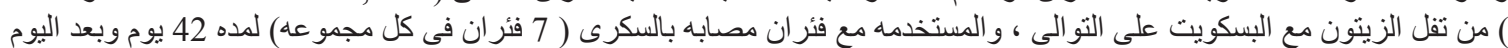

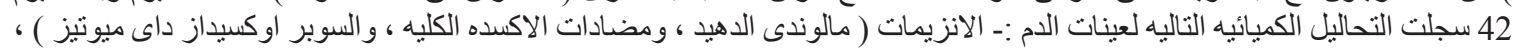

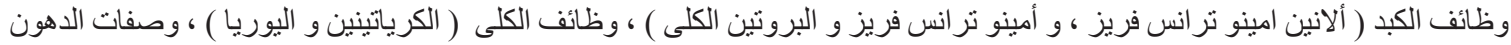

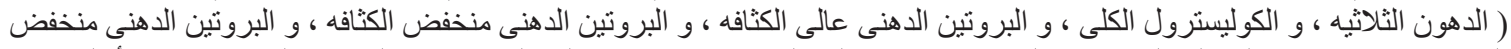

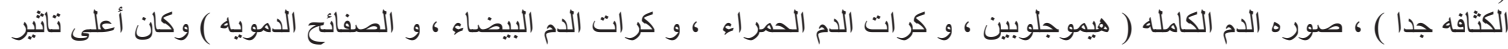

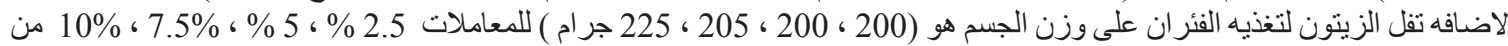

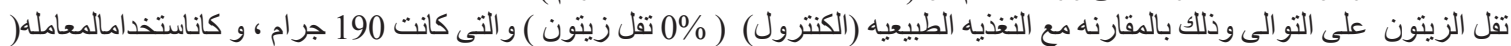

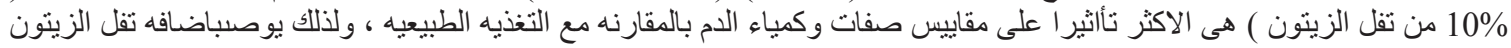

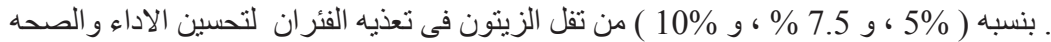

